\title{
PERINATAL MORTALITY IN HOSPITALS OF THE STATE OF SÃO PAULO: METHODOLOGICAL ASPECTS AND SOME CHARACTERISTICS OF MOTHERS AND CONCEPTUSES
}

\author{
Ruy Laurenti ${ }^{1}$, Arnaldo Augusto Franco de Siqueira ${ }^{1}$, Maria Helena Prado de Mello Jorge ${ }^{1}$, \\ Sabina Léa Davidson Gotlieb ${ }^{1}$, Elaine Cristina Pimentel ${ }^{1}$
}

\begin{abstract}
Objective: to verify perinatal mortality and its associated components in an investigation about the history of gestations/deliveries. Methods: the study was carried out at six maternity hospitals in the State of São Paulo that were interested in participating in the research. The population was composed of 7,058 women, of whom 6,530 gave birth, the number of conceptuses was 6,602: 56 stillbirths and 6,546 live births, of which 28 died in the first week of life. Variables related to the mother, the pregnancy, the delivery and the conceptus were studied. Results: the perinatal mortality coefficient was 12.7 per 1,000 births, $66.7 \%$ of the conceptuses were stillbirths and $33.3 \%$ were live births who died aged less than 7 days at the same hospital where they were born. Approximately $27 \%$ of the conceptuses were children of adolescent mothers and $44 \%$ of the mothers were primigravidae. Prenatal assistance was attended by $92 \%$ of the women, type of pregnancy showed $67.8 \%$ of preterm gestations with similar proportions for each one of the components. The coefficient for twin gestations was more than four times higher than the coefficient for mothers of singleton gestations. Regarding type of delivery, Cesarean sections corresponded to $31.1 \%$ of the total, and it is important to notice that there was a non-negligible amount of surgical deliveries in mothers whose product was a stillbirth. The coefficient according to sex was higher for males (1.8: 1), and as for birth weight, the highest proportion occurred among those who weighed less than $2,500 \mathrm{~g}(67.9 \%)$. Conclusions: there was a relationship of the proportion of neonatal deaths in the first hours of life and the proportion of fetal deaths to the quality of the care offered in the women's pregnancypuerperal cycle.
\end{abstract}

Key words: pregnancy, maternal and child health, health statistics, perinatal mortality.

\section{INTRODUCTION}

The term "perinatal" was proposed in 1940 by Peller, who, since 1923, considered necessary to analyze, as one "statistical unit", the sum of the numbers of stillbirths and neonates who died during the first postnatal week. To the statisticians, the use of this concept facilitated international comparisons, and clinicians and epidemiologists realized that the two components of perinatal mortality were subject to the same causal factors, of prenatal and intranatal nature.

The factors that contribute to early fetal and infant mortality can be divided into two groups: one contains factors that can usually be prevented, which are called exogenous, socioeconomic or environmental (nutrition, income, sanitation, occupation, etc.), and the other contains factors that are known as endogenous, or associated with development, or biological.

It is necessary to clarify that there is no perfect dichotomy of situation, with the two groups of factors acting in isolation, in defined periods of time (as, in fact, these periods are arbitrary). On the contrary, as Hammond ${ }^{1}$ emphasizes, there is a continuum that begins nine months before birth conception - and lasts until the $1^{\text {st }}$ year of life, with biological and environmental factors interacting with each another.

As diseases caused by environmental factors were gradually prevented, infant mortality decreased. The endogenous factors (whose prevention is more difficult) have maintained a slower reduction rate for fetal and early neonatal mortality.

1 Epidemiology Department of the School of Public Health of Universidade de São Paulo (USP). Avenida Dr. Arnaldo, 715 São Paulo - SP CEP 01246-904 Brazil.

Funding: Fundação de Amparo à Pesquisa do Estado de São Paulo (Project no. 09/53253-8)

Corresponding Author: laurenti@usp.br

Suggested citation: Laurenti $\mathrm{R}$, et al. Perinatal mortality in hospitals of the state of São Paulo: methodological aspects and some characteristics of mothers and conceptuses, Journal of Human Growth and Development 2013, 23(3): 261-269

Manuscript submitted Oct 08 2013, accepted for publication Nov 202013. 
The $10^{\text {th }}$ Revision of the International Classification of Diseases, which has been in force in Brazil since $1996^{2}$, changed the definition of perinatal period: it ranges from 22 completed weeks (154 days) of gestation (the time when birth weight is normally $500 \mathrm{~g}$ ) to 6 completed days after birth.

It is well known what has happened with infant mortality: it has decreased significantly in the post-neonatal (late infant) period and now concentrates on the neonatal period and, within it, on the first days after birth. Due to this fact, studies/ analyses of perinatal mortality have been increasingly conducted in order to learn its causes and factors so that it is possible to offer subsidies for action aiming at its reduction and, consequently, at the reduction in neonatal and infant mortality.

When perinatal mortality is analyzed, and mainly its causes are investigated, the study focuses almost exclusively on the early neonatal component and little attention is given to the stillbirth component. Fonseca and Coutinho ${ }^{3}$ argue that fetal mortality should be analyzed separately from perinatal mortality because, while early neonatal mortality has been significantly reduced in Brazil, fetal mortality is still quite high. It is important to remember that only a few countries produce stillbirth statistics according to causes and variables of epidemiological interest, the majority of the nations present only the number of stillbirths in order to calculate the perinatal mortality coefficient. Another fact is that some countries started to publish data on perinatal mortality only from 1979 onwards. ${ }^{4}$

Even when there is a declaration of stillbirth, in which the physician declares the cause and variables such as mother's age and gestation period, among others, no information is requested for some characteristics that are also important, like prenatal assistance, pregnancy complications, and number of previous gestations. Such data could only be obtained by means of a field investigation about the pregnant women and their conception products.

Therefore, the aim of this study is to verify perinatal mortality and its associated components in an investigation of the history of gestations/ deliveries.

\section{METHODS}

The study's population was composed of 7,058 women hospitalized due to abortion or delivery that occurred during three months of the $2^{\text {nd }}$ semester of 2011, at six maternity hospitals of the State of São Paulo. Four of them were located in the capital city, and two, in cities in the interior of the State. Regarding the type of patient, five maternity hospitals assisted exclusively people through the Sistema Único de Saúde (SUS - Brazil's National Healthcare System) and one, only patients with private healthcare plans.

The study was descriptive and cross-sectional and, although the results refer to a large number of women and their conceptuses, it is important to remember that they do not represent the population of pregnant women of the State of São Paulo, as we did not employ sampling techniques for their selection. The hospitals' participation depended on the interest of their directors. Thus, in the city of São Paulo, four of the largest maternity hospitals with population assisted by the SUS accepted to participate (one of them was a university hospital), in the interior of the State, two hospitals accepted to participate in the research, and one of them was also a university hospital.

The data were collected directly in interviews with the hospitalized women and from the hospitals' medical records, the women's prenatal cards and similar documents. The answers were noted down on a form that was created to the set of selected variables.

For data calculation, the application $A B B Y Y$ FlexiCapture ${ }^{T M}$ was used. It was possible to automatically convert the data of the forms into utilizable and accessible data to be exported to any database applications. The cases were exported from the $A B B Y Y$ application to the Microsoft Exce/ ${ }^{T M}$ format.

The studied material refers to 56 stillbirths and 6,546 live births, 28 of the latter died in the first week of life, at the same hospital where the delivery occurred. This set is referred to as conceptuses. These conceptuses corresponded to the gestation products of 6,530 women.

The list of live births at the four hospitals in the city of São Paulo, with mother's name, date of birth, and place of birth, was sent to and examined by the Programa de Aprimoramento das Informações de Mortalidade (PROAIM - Program for Improvement in Mortality Information), of the municipal government of São Paulo, in order to investigate if any neonates died in the first week of life, after being discharged from the hospital where they were born.

The analyzed variables regard some characteristics of the mother, of the pregnancy, of the delivery and of the product. In relation to maternal characteristics, the following aspects were selected: age, level of schooling, work conditions, marital status, habits such as smoking, alcohol consumption and drug use, and number of previous pregnancies.

The results are presented in the form of proportions (\%) and coefficients of perinatal mortality, of stillbirth and of early neonatal mortality, calculated according to an international definition. ${ }^{2}$ In this study, the coefficient refers, as it was mentioned above, to deaths that occurred at the same hospital where the birth took place (hospital perinatal mortality coefficient - HPMC). The analysis was performed to all the variables, however, in some cases, its values should be seen with caution, due to the existence of low frequencies.

The Project was approved by the Research Ethics Committees of the School of Public Health of 
the University of São Paulo and of the participant hospitals. Data collection only occurred after the pregnant women signed a consent document and after the hospitals agreed.

\section{RESULTS}

The hospital perinatal mortality coefficient was 12.7 per 1,000 births. It is important to highlight that $66.7 \%$ of the conceptuses corresponded to stillbirths and $33.3 \%$ to neonates who died subsequently, aged less than 7 days.

The analysis of maternal age (Table 1 ) revealed that $27.4 \%$ of the conceptuses were children of adolescent mothers (10 to 19 years), $55.9 \%$, of mothers aged 20 to 34 years, and $16.7 \%$, of mothers aged 35 or older. It is possible to notice that the lowest value occurred in the group of mothers aged 20 to 34 years, considered as the "optimal age" group (10.2 per 1,000 births). Among the adolescent mothers, the HPMC was 16.6 per 1,000 births, and it reached 22.7 per 1,000 births among older mothers.

As for level of schooling, the highest proportion of deaths was found among conceptuses of mothers who had completed Secondary School $(44 \%)$, followed by mothers who had completed Primary School. The proportion of mothers who were working at the time of the birth was $45.2 \%$, a value that was similar to that of women who answered that they did not work. Of the total, $2.4 \%$ were unemployed and $4.8 \%$ were students at the time of the birth (Table 1 ).

The analysis of marital status showed that almost $80 \%$ of the women answered that they lived with husband/partner, and, among those whose products were stillbirths, the proportion was even higher $(85.7 \%)$.

Regarding the habits of smoking, alcohol consumption and drug use during pregnancy, the proportions of mothers of stillbirths who confirmed

Table 1: Number and proportion (\%) of perinatal deaths and its components, live births and hospital perinatal mortality coefficient according to some maternal characteristics, at six maternity hospitals in the State of São Paulo, 2011

\begin{tabular}{|c|c|c|c|c|c|c|c|c|}
\hline \multirow[t]{2}{*}{$\begin{array}{c}\text { Maternal } \\
\text { characteristics }\end{array}$} & \multicolumn{2}{|c|}{$\begin{array}{l}\text { Stillbirths } \\
\text { (56) }\end{array}$} & \multicolumn{2}{|c|}{$\begin{array}{c}\text { Early } \\
\text { neonatal } \\
\text { deaths (28) }\end{array}$} & \multicolumn{2}{|c|}{$\begin{array}{l}\text { Total } \\
(84)\end{array}$} & \multirow{2}{*}{$\begin{array}{c}\text { Live } \\
\text { births } \\
(6,546) \\
\text { No }\end{array}$} & \multirow{2}{*}{ 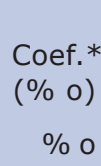 } \\
\hline & \multicolumn{5}{|c|}{ Age (in years) } & & & \\
\hline 10 to 19 & 16 & 28.6 & 7 & 25,0 & 23 & 27.4 & 1,367 & 16.6 \\
\hline 20 to 34 & 28 & 50.0 & 19 & 67,9 & 47 & 55.9 & 4,574 & 10.2 \\
\hline 35 or older & 12 & 21.4 & 2 & 7,1 & 14 & 16.7 & 605 & 22.7 \\
\hline \multicolumn{9}{|l|}{ Level of schooling } \\
\hline None & 1 & 1.8 & - & - & 1 & 1.2 & 8 & 111.1 \\
\hline Incomplete Primary School & 9 & 16.1 & 6 & 21,4 & 15 & 17.9 & 1,029 & 14.5 \\
\hline Complete Primary School & 15 & 26.8 & 8 & 28,6 & 23 & 27.4 & 2,020 & 11.3 \\
\hline Complete Secondary School & 25 & 44.7 & 12 & 42,9 & 37 & 44.0 & 3,046 & 12.0 \\
\hline Complete Higher Education & 3 & 5.3 & 2 & 7,1 & 5 & 5.9 & 225 & 21.9 \\
\hline Ignored & 3 & 5.3 & - & - & 3 & 3.6 & 218 & - \\
\hline \multicolumn{9}{|l|}{ Work } \\
\hline Currently working & 26 & 46.4 & 12 & 42,9 & 38 & 45.2 & 2,807 & 13.4 \\
\hline Does not work & 26 & 46.4 & 13 & 46,4 & 39 & 46.4 & 3,263 & 11.9 \\
\hline Unemployed & 1 & 1.8 & 1 & 3,6 & 2 & 2.4 & 242 & 8.2 \\
\hline Student & 2 & 3.6 & 2 & 7,1 & 4 & 4.8 & 143 & 27.6 \\
\hline Ignored & 1 & 1.8 & - & - & 1 & 1.2 & 91 & - \\
\hline \multicolumn{9}{|l|}{ Marital Status } \\
\hline Lives with husband/partner & 48 & 85.7 & 19 & 67,9 & 67 & 79.7 & 5,016 & 13.2 \\
\hline Lives with other relatives & 7 & 12.5 & 7 & 25,0 & 14 & 16.7 & 1,206 & 11.5 \\
\hline Lives alone/with children & - & - & 2 & 7,1 & 2 & 2.4 & 263 & 7.6 \\
\hline Ignored & 1 & 1.8 & - & - & 1 & 1.2 & 61 & - \\
\hline \multicolumn{9}{|l|}{ Habits } \\
\hline Smoking (yes) & 6 & 10.7 & 4 & 14,3 & 10 & 11.9 & 916 & 10.8 \\
\hline Alcohol (yes) & 1 & 1.8 & 7 & 25,0 & 8 & 9.5 & 693 & 11.5 \\
\hline Drugs (yes) & 1 & 1.8 & 1 & 3,6 & 2 & 2.4 & 84 & 23.5 \\
\hline \multicolumn{9}{|c|}{ No. of previous pregnancies } \\
\hline None & 23 & 41.1 & 14 & 50,0 & 37 & 44.0 & 2,779 & 13.2 \\
\hline 1 and 2 & 24 & 42.8 & 10 & 35,7 & 34 & 40.5 & 2,837 & 11.9 \\
\hline 3 and 4 & 7 & 12.5 & 2 & 7,1 & 9 & 10.7 & 742 & 12.0 \\
\hline 5 or more & 2 & 3.6 & 2 & 7,1 & 4 & 4.8 & 182 & 21.7 \\
\hline Ignored & - & - & - & - & - & - & 6 & - \\
\hline
\end{tabular}

* per 1,000 births 
their use were $10.7 \%, 1.8 \%$ and $1.8 \%$, respectively, and $14.3 \%, 25 \%$ and $3.6 \%$ were the values for the mothers of neonates who died.

In the question concerning the number of previous pregnancies, $44 \%$ answered they were primigravidae, $41.1 \%$ among mothers of stillbirths and $50 \%$ among mothers of neonates who died in the first 7 days of life.
As for the characteristics of the pregnancy and delivery, the following aspects were studied: prenatal assistance (number of consultations and the initial month), gestational age (in weeks), type of pregnancy, type of delivery and maternal pathologies (Table 2).

The great majority of the women $(91.7 \%)$ received prenatal assistance, and there were

Table 2: Number and proportion (\%) of perinatal deaths and its components, live births and hospital perinatal mortality coefficient according to characteristics of the pregnancy and delivery, at six maternity hospitals in the State of São Paulo, 2011

\begin{tabular}{|c|c|c|c|c|c|c|c|c|}
\hline \multirow[t]{2}{*}{$\begin{array}{l}\text { Characteristics of the } \\
\text { pregnancy and delivery }\end{array}$} & \multicolumn{2}{|c|}{$\begin{array}{l}\text { Stillbirths } \\
\quad(56)\end{array}$} & \multicolumn{2}{|c|}{$\begin{array}{c}\text { Early } \\
\text { neonatal } \\
\text { deaths }(28)\end{array}$} & \multicolumn{2}{|c|}{$\begin{array}{r}\text { Total } \\
(84)\end{array}$} & \multirow{2}{*}{$\begin{array}{c}\text { Live } \\
\text { births } \\
(6,546) \\
\text { No }\end{array}$} & \multirow{2}{*}{$\begin{array}{l}\text { Coef. } \\
\left(\begin{array}{l}\% \\
\%\end{array}\right) \\
\% \text { o }\end{array}$} \\
\hline & No. & $\%$ & No. & $\%$ & No. & $\%$ & & \\
\hline None & 3 & 5.4 & 4 & 14.3 & 7 & 8.3 & 77 & 87.5 \\
\hline 1 to 3 & 17 & 30.4 & 2 & 7.1 & 19 & 22.6 & 402 & 45.3 \\
\hline 4 to 6 & 17 & 30.4 & 12 & 42.9 & 29 & 34.5 & 1,560 & 18.4 \\
\hline 7 to 11 & 9 & 16.1 & 8 & 28.6 & 17 & 20.3 & 3,737 & 4.5 \\
\hline 12 or + & 5 & 8.9 & - & - & 5 & 6.0 & 608 & 8.2 \\
\hline Ignored the no. & 5 & 8.9 & 2 & 7.1 & 7 & 8.3 & 151 & - \\
\hline Ignored & - & - & - & - & - & - & 11 & - \\
\hline \multicolumn{9}{|l|}{ Prenatal (initial trim.)* } \\
\hline $1^{\text {st }}$ trimester & 39 & 73,6 & 21 & 87,5 & 60 & 77,9 & 4.739 & 12,6 \\
\hline $2^{\text {nd }}$ trimester & 10 & 18.9 & 3 & 12.5 & 13 & 16.9 & 1,382 & 9.3 \\
\hline $3^{\text {rd }}$ trimester & 4 & 7.5 & - & - & 4 & 5.2 & 211 & 18.6 \\
\hline Ignored & - & - & - & - & - & - & 126 & - \\
\hline \multicolumn{9}{|l|}{$\mathrm{GA}$ (in weeks) } \\
\hline Preterm & 38 & 67.9 & 19 & 67.8 & 57 & 67.8 & 609 & 88.1 \\
\hline Term & 17 & 30.3 & 8 & 28.6 & 25 & 29.8 & 5,815 & 4.3 \\
\hline Post-term & - & - & - & - & - & - & & - \\
\hline Ignored & 1 & 1.8 & 1 & 3.6 & 2 & 2.4 & 32 & - \\
\hline \multicolumn{9}{|l|}{ Type of pregnancy } \\
\hline Singleton & 53 & 94.6 & 24 & 85.7 & 77 & 91.7 & 6,407 & 11.9 \\
\hline Twin & 3 & 5.4 & 4 & 14.3 & 7 & 8.3 & 133 & 51.5 \\
\hline Triplet & - & - & - & - & - & - & 6 & \\
\hline \multicolumn{9}{|l|}{ Type of delivery } \\
\hline Vaginal & 49 & 87,5 & 16 & 57,1 & 65 & 77,4 & 3.974 & 16,2 \\
\hline Forceps & - & - & 1 & 3,6 & 1 & 1,2 & 524 & 1,9 \\
\hline Cesarean & 7 & 12,5 & 11 & 39,3 & 18 & 21,4 & 2.048 & 8,8 \\
\hline \multicolumn{9}{|l|}{ Maternal pathologies } \\
\hline Yes & 39 & 69.6 & 13 & 46.4 & 52 & 61.9 & 4,368 & 11.8 \\
\hline
\end{tabular}

* Refers only to mothers who received prenatal assistance

** per 1,000 births

different proportions concerning the number of consultations, depending on the type of conceptus. Thus, $60.8 \%$ of the mothers of stillbirths and $50 \%$ of the mothers whose babies died in the $1^{\text {st }}$ week of life attended less than 7 prenatal consultations. Regarding the beginning of prenatal assistance, the majority of the women (77.9\%) started attending it in the first trimester of pregnancy $(73.6 \%$ for the mothers of stillbirths and $87.5 \%$ for the mothers of babies who died in the early neonatal period).

As for gestational age, preterm conceptuses were considered those of less than 37 weeks of gestation, term conceptuses were considered those of 37 to 41 weeks, and post-term conceptuses, those with 42 completed weeks or more. ${ }^{2}$ Among the perinatal deaths, $67.8 \%$ were of preterm babies, with similar proportions in each one of the components.
Regarding type of pregnancy, the proportion of twin gestations was $5.4 \%$ among the mothers of stillbirths, and $14.3 \%$ among the mothers of conceptuses who died in the early neonatal period. The perinatal mortality coefficient among conceptuses of twin gestations was more than 4 times higher than the coefficient corresponding to the mothers of singleton pregnancies.

In relation to type of delivery, Table 3 shows differences in Cesarean section rates of women who delivered live births or stillbirths. The rates were calculated based on the relationship between women submitted to Cesarean sections and the total number of women or, as it is usually performed, on the proportion of children born from Cesarean sections divided by the total number of live births. Thus, for the stillbirths, the values were $12.5 \%$ if based on the conceptuses, and $11 \%$ if based on the mothers. 
Table 3: Number and proportion of cesarean and vaginal deliveries in relation to mothers and conceptuses, according to type of product, at six maternity hospitals in the State of São Paulo, 2011

\begin{tabular}{|c|c|c|c|c|}
\hline \multirow{2}{*}{$\begin{array}{l}\text { Type of delivery/product } \\
\text { Stillbirth }\end{array}$} & \multicolumn{2}{|c|}{ Woman } & \multicolumn{2}{|c|}{ Conceptus } \\
\hline & No. & $\%$ & No. & $\%$ \\
\hline Vaginal & 48 & 88.9 & 49 & 87.5 \\
\hline Cesarean & 6 & 11.1 & 7 & 12.5 \\
\hline Total & 54 & 100.0 & 56 & 100.0 \\
\hline \multicolumn{5}{|l|}{ Live birth } \\
\hline Vaginal & 4,476 & 69.1 & 4,498 & 68.7 \\
\hline Cesarean & 1,999 & 30.9 & 2,048 & 31.3 \\
\hline Total & 6,475 & 100.0 & 6,546 & 100.0 \\
\hline \multicolumn{5}{|l|}{ Live birth + stillbirth } \\
\hline Vaginal & - & - & - & \\
\hline Cesarean & 1 & 100.0 & - & - \\
\hline Total & 1 & 100.0 & - & \\
\hline \multicolumn{5}{|l|}{ TOTAL } \\
\hline Vaginal & 4,524 & 69.3 & 4,547 & 68.9 \\
\hline Cesarean & 2,006 & 30.7 & 2,055 & 31.1 \\
\hline Total & 6,530 & 100.0 & 6,602 & 100.0 \\
\hline \multicolumn{5}{|l|}{ LB early neonatal death } \\
\hline Vaginal & 16 & 61.5 & 17 & 60.7 \\
\hline Cesarean & 10 & 38.5 & 11 & 39.3 \\
\hline Total & 26 & 100.0 & 28 & 100.0 \\
\hline
\end{tabular}

The presence of health problems during the current pregnancy was verified in almost $62 \%$ of the puerperal women who lost their conceptuses in the perinatal period.

The following characteristics of the conceptuses were selected: the variables sex, birth weight and presence of congenital anomalies and other pathologies, as well as the causes that led to the death of the fetus or neonate (Table 4). Regarding deaths according to sex, it was found that $60.7 \%$ were males, $31.0 \%$ were females and $1.2 \%$ were of indeterminate sex as a result of congenital malformations, there was no information about the others $(7.1 \%)$. The hospital perinatal mortality coefficient according to sex was 14.9 per 1,000 male births and 8.2 per 1,000 female births.

Table 4: Number and proportion (\%) of perinatal deaths and its components, live births and hospital perinatal mortality coefficient according to characteristics of the conceptuses, at six maternity hospitals in the State of São Paulo, 2011

\begin{tabular}{|c|c|c|c|c|c|c|c|c|}
\hline \multirow[t]{2}{*}{$\begin{array}{c}\text { Characteristics of the } \\
\text { conceptus }\end{array}$} & \multicolumn{2}{|c|}{$\begin{array}{l}\text { Stillbirths } \\
\quad(56)\end{array}$} & \multicolumn{2}{|c|}{$\begin{array}{c}\text { Early } \\
\text { neonatal } \\
\text { deaths (28) }\end{array}$} & \multicolumn{2}{|c|}{$\begin{array}{l}\text { Total } \\
(84)\end{array}$} & \multirow{2}{*}{$\begin{array}{c}\text { Live } \\
\text { births } \\
(6,546) \\
\text { No }\end{array}$} & \multirow{2}{*}{$\begin{array}{r}\text { Coef.* }^{*} \\
\text { (\% o o }) \\
\% \text { o }\end{array}$} \\
\hline & No. & $\%$ & No. & $\%$ & No. & $\%$ & & \\
\hline $\begin{array}{l}\text { Male } \\
\text { Mex }\end{array}$ & 33 & 58.9 & 18 & 64.3 & 51 & 60.7 & 3,383 & 14.9 \\
\hline Female & 16 & 28.6 & 10 & 35.7 & 26 & 31.0 & 3,162 & 8.2 \\
\hline Indeterminate & 1 & 1.8 & - & - & 1 & 1.2 & 1 & \\
\hline Ignored & 6 & 10.7 & - & - & 6 & 7.1 & - & \\
\hline \multicolumn{9}{|l|}{ Birth weight } \\
\hline Below 2500g & 36 & 64.3 & 21 & 75.0 & 57 & 67.9 & 539 & 99.1 \\
\hline $2500 \mathrm{~g}$ or more & 14 & 25.0 & 7 & 25.0 & 21 & 25.0 & 6,005 & 3.5 \\
\hline Ignored & 6 & 10.7 & - & - & 6 & 7.1 & 2 & - \\
\hline $\begin{array}{l}\text { Congenital anomalies } \\
\text { (yes) }\end{array}$ & 6 & 10,7 & 8 & 28,6 & 14 & 16,7 & 269 & 2,1 \\
\hline (yes) & $\ldots$ & $\ldots$ & 17 & 60.7 & 17 & 20.2 & 1,682 & \\
\hline
\end{tabular}

* per 1,000 births

Birth weight was studied according to the international concept, whose cut-off point between adequate weight and low weight is $2,500 \mathrm{~g} .^{2}$ The highest proportion occurred among those who weighted less than $2,500 \mathrm{~g}(67.9 \%)$, among the stillbirths, regarding the early neonatal deaths (respectively, 64.3\% and 75\%), conceptuses with adequate weight represented one fourth of the cases. 
The proportion of conceptuses with congenital anomaly was $16,7 \%$, also with very different values in the two components $(10,7 \%$ among stillbirths and $28,6 \%$ in the neonates who died). The variable "presence of another pathology" was researched only for neonates who died and was $60.7 \%$.

\section{DISCUSSION}

Perinatal mortality, including its two components, has been an important health indicator for studies of mother-child health and also regarding the conditions of obstetric care and the communities' level of economic development. ${ }^{5}$ However, its study has not been more comprehensive due to the difficulties that exist, mainly concerning stillbirths. Lansky et al. ${ }^{6}$ state that this component corresponds to the "invisible" side of the problem.

In Brazil, the Mortality Information System of the Ministry of Health includes the records of stillbirths. They are recorded on the same document that is used for non-fetal deaths (Death Certificate), but the count and presentation of stillbirths are recorded separately. ${ }^{4}$ The System's quality has been gradually improving. ${ }^{7}$ Nevertheless, concerning stillbirths, it still has much space for enhancements, both from the quantitative and qualitative points of view. For this reason, the Rede Interagencial de Informações para a Saúde (RIPSA - Interagency Network on Health Information) recommends its direct calculation only for some Brazilian States ${ }^{8,9}$. From the qualitative point of view, Almeida et al. ${ }^{10}$ argue that, even when the body is submitted to a necropsy, the cause of the fetal loss is still not indicated adequately. Because of these problems, some authors have proposed the use of the Hospital Information System as a source to estimate neonatal mortality and stillbirths. ${ }^{11}$ In light of this, studies on perinatal mortality based on field research have proved to provide the most clarifying explanations regarding the problems that may occur with the mother and her conceptus, aiming to provide subsidies for the prevention of avoidable deaths within this group.

The hospital perinatal mortality coefficient obtained in this investigation was 12.7 per 1,000 births, a value that is different from the ones found by Miura et al. ${ }^{12}$ (28.4 per 1,000 births) and Fonseca and Coutinho ${ }^{3}$ (25.0 per 1,000 births), but which is similar to the values verified in a study conducted in Rio de Janeiro ${ }^{13,14}$, and also to the official data of the State of São Paulo ${ }^{9}$ and of the city of São Paulo ${ }^{15}$. In many countries, the coefficient' values are lower: in the United States of America, the value is 7.1 per 1,000 births, and in Sweden, it is 5.4 per 1,000 births, for the period 1995/1998. ${ }^{13}$

However, some reflections should be made. The present research adopted the international concepts in force for the events live birth and stillbirth, and complied with the limits established for the perinatal period, although it was verified that, in some hospitals, these limits were not respected, thus, it was necessary to correct them in the study (there were five cases of stillbirths that had been considered as abortions by the hospital). The deaths that occurred in the first week of life may not represent the totality of deaths in the early neonatal period, as only the events that happened at the same hospital in which the birth occurred were considered. Among the live births, some were transferred to other institutions due to health problems. For this reason, a higher number of early neonatal deaths may have occurred. It is important to highlight, however, that the search performed by PROAIM upon our request did not find any early neonatal death for children born in the hospitals of this study that occurred at another hospital (not the hospital where the child was born). There was only one case in which the neonate was transferred to another hospital, where it eventually died. Thus, it is not likely that in the two other hospitals located in other cities not covered by PROAIM this scenario was different.

The proportion that was found of stillbirths and early neonatal deaths in perinatal mortality approximately $\mathrm{T}$ ! and S!, respectively - follows the expected pattern, both national and international. ${ }^{16}$ Nevertheless, it is necessary to ponder that, although this pattern is similar to that of other studies, this "balance" occurred in much higher values, that is, there was an excessive number of early neonatal deaths and an even higher excess of intrauterine deaths. If we take into account that, in approximately $10 \%$ of the fetal losses, the death occurred after the mother was hospitalized, it is possible to consider that the quality of the care provided for the mother/child binomial in the antenatal period is not satisfactory.

As for maternal characteristics, age stands out as relevant, as the perinatal mortality coefficient is lower in the group of mothers aged 20 to 34 years (10.2 per 1,000 births), increasing by approximately $63 \%$ for the adolescent mothers, and even more for the older mothers: 22.7 per 1,000 births, a value that corresponded to more than twice the value considered of lowest risk. Regarding level of schooling, the data confirm the findings of other studies, in which the lower the level of schooling, the higher the HPMC value. The majority of the women whose conceptuses died in the perinatal period were primigravidae, and approximately $5 \%$ corresponded to grand multiparous women (five or more previous pregnancies).

Authors have shown that specific perinatal mortality coefficients for maternal age and multiple births are useful to monitor perinatal deaths better, as they allow comparisons over time, independently of the changes occurred in the women's reproductive profiles. In addition, they enable to draw more adequate comparisons for different places and to better evaluate the impact on the healthcare services. ${ }^{17}$ 
There was high coverage of prenatal consultations and low proportion of women without any assistance $(8.3 \%)$. The Ministry of Health recommends, as an adequate value, 7 or more consultations $^{8}$, a proportion that, here, totaled $26.3 \%$. The mothers of stillbirths and of early neonatal deaths present, however, different behaviors: among the former, the great concentration occurred in the class 1 to 6 consultations $(60.8 \%)$. One possible explanation derives from the shorter duration of the gestation, as in $67.9 \%$ of the conceptuses, the gestational age at the moment of delivery was below 37 weeks. It is possible to conclude that absence of prenatal assistance is an important risk factor to the health of the mother-child binomial.

Concerning type of delivery, although the WHO recommends that the proportion of cesarean deliveries should not be higher than $15 \%{ }^{18}$ and some authors admit a maximum of $12 \%$, values in Brazil are much higher. In the United States, in 2009, the Cesarean section rate was $32.9 \%$ of all births, showing a $60 \%$ increase in relation to the 1996 figure (20.7\%). ${ }^{19}$ Among the mothers of live births of the present study, the global proportion of Cesarean sections was $31.1 \%$, therefore, it is possible to raise the hypothesis related to the existence of unnecessary surgical deliveries. Rattner et al. ${ }^{20}$ mention that the increase in Cesarean section rates results from numerous factors, including better access to the Healthcare Systems, greater availability of technologies, better surgical techniques and anesthetics, not to mention the "preference" of care providers and patients.

The proportion of Cesarean sections in this study can be considered satisfactory, if we take into account that two of the maternity hospitals are reference for high-risk pregnancies and, in all of them, the predominant clientele belonged to the lowest income strata of the population. This "low" proportion of Cesarean sections can be compared to the figures of $53.7 \%$ and $60.0 \%$ of Cesarean sections in Brazil and in the State of São Paulo in 2011, for example, and of $53.9 \%$ in the city of São Paulo*. In fact, it should be recognized that, in public hospitals, especially university hospitals, the majority of the Cesarean sections usually have an obstetric indication, unlike what is observed in private maternity hospitals, whose proportions of Cesarean sections are above $80 \%$. Concerning this aspect, it is important to cite the study carried out by Ventura ${ }^{21}$ at the University Hospital of Universidade de São Paulo (USP), which found a Cesarean section rate of $28.4 \%$.

In this aspect, the high proportion of Cesarean sections in mothers of stillbirths was unexpected $(12.5 \%)$. In a previous study, referring to the period 1968-70, Laurenti, Silveira and Siqueira 22 had already showed a proportion of Cesarean sections of $10 \%$. These values are unacceptable, as there is no plausible indication of Cesarean sections for stillbirths, given the risk that the procedure imposes on the pregnant woman, without any benefit to the fetus, which is already dead. A low proportion, close to zero, would be expected, as in some case the death might have occurred between the indication and the performance of the procedure. This result, like the one reported in 1975, allows to consider that the quality of the care provided for the mother/ fetus binomial is unsatisfactory, as it was mentioned above. In addition, the case-to-case study of the intrauterine deaths of this study enabled us to verify that, in approximately $10 \%$ of the cases, fetal death occurred after the pregnant woman was hospitalized, a sign of the poor quality of labor monitoring. Therefore, we believe that it is possible to conclude that the procedures involved need to be reviewed and improved, and special attention should be paid to obstetric training.

With regard to mothers' pathologies during pregnancy, independently of the type, they occurred in almost $70 \%$ of the women who had stillbirths and in $46.4 \%$ of those whose baby died in the first week of life.

The distribution of the perinatal deaths according to sex showed a clear predominance of males over females, a fact that has been observed in all countries ${ }^{23}$. The male coefficient was 1.8 times higher than the female one.

As for birth weight, the perinatal mortality coefficient was 99.1 per 1,000 births for low weight conceptuses and 3.5 for those who presented adequate birth weight, for the cases of extremely low birth weight, the coefficient was 617 per 1,000 births. According to Aquino ${ }^{24}$, mortality is higher in fetuses weighing less than 2,500 g, and Barros et al. ${ }^{25}$ inform that low birth weight conceptuses have a risk of perinatal death that is 17 times higher.

The distribution of deaths in the first week of life behaved as it was expected, with concentration on the first 24 hours (18 deaths - 64.3\%), followed by six deaths of babies aged one day $(21.4 \%)$, two deaths of babies aged two days and two deaths of babies aged six days, a proportion that is similar to what has been found in studies conducted by other authors. ${ }^{26}$

It was mentioned above that not all countries perform the obligatory register of stillbirths, a fact that is an important obstacle for studies about the problem. From the standpoint of quality, the official information is often precarious, as many physicians - sometimes, even after the necropsy - do not indicate the cause of the loss, and do not even inform if it was a maternal or a fetal cause.

It was possible to observe, in this research, that:

1) Regarding the stillbirth component, the methodology allowed to recover five cases that 
the hospital had considered as abortions and the study considered as stillbirths, in view of the concept that gives equal importance to gestation period or weight or size..$^{2,27}$. Concerning the causes, of the 56 stillbirths, it was found that, in 23 cases, the study considered a maternal cause as being responsible for the loss, in seven, the cause was attributed to the conceptus (five congenital anomalies, one true knot of the umbilical cord, and one case of macrosomia), in two, there was reference to maternal and fetal causes. Despite the methodology of consulting the medical record, in 20 cases $(35.7 \%)$ the cause remained undetermined. We would like to emphasize that one fourth of these cases corresponded to the above-mentioned situation of stillbirth that had been considered as abortion by the hospital, and

\section{REFERENCES}

1. Hammond EI. Studies in fetal and infant mortality. A methodological approach to the definition of perinatal mortality. Am J Public Health Nations Health. 1965 August, 55(8): 1152-1163.

2. Organização Mundial de Saúde. Classificação Estatística Internacional de Doenças e Problemas Relacionados à Saúde - CBCD, S.Paulo, 2008 (v.2).

3. Fonseca SC e Coutinho ESF. Pesquisa sobre mortalidade perinatal no Brasil: revisão da metodologia e dos resultados. Cad. Saúde Pública, Rio de Janeiro, 20 Sup 1:S7-S19, 2004.

4. Laurenti R, Mello Jorge MH. O atestado de óbito. São Paulo, CBCD, 2007.

5. Yu V. Global, regional and national perinatal and neonatal mortality. J Perinat Med 2003, 31:3769. Doi: 10.3126/jnps.v32i2. 6898

6. Lansky S, França E, Leal MC. Mortalidade perinatal e evitabilidade: revisão da literatura. Rev Saúde Pública 2002,36(6):759-72 .

7. Jorge MHPM, Laurenti R, Gotlieb SLD. Análise da qualidade das estatísticas vitais brasileiras: a experiência de implantação do SIM e do SINASC. Cien Saude Colet, 2007, 12(3):643654. Doi: $10.1590 /$ S1413-8123200700030 0014

8. REDE Interagencial de Informação para a Saúde Indicadores básicos para a saúde no Brasil: conceitos e aplicações / Rede Interagencial de Informação para a Saúde - Ripsa. - 2. ed. Brasília: Organização Pan-Americana da Saúde, 2008. 349 p.: il.

9. Brasil. Ministério da Saúde. Secretaria de Vigilância em Saúde. Departamento de Análise de Situação de Saúde. Saúde Brasil 2011 : uma análise da situação de saúde e a vigilância da saúde da mulher / Ministério da Saúde, Secretaria de Vigilância em Saúde, Departamento de Análise de Situação de Saúde. for this reason, there was nothing in the form that could clarify the cause of death,

2 ) In relation to the early neonatal component, the 28 deaths presented the following basic causes: one $(3.6 \%)$ maternal cause, 12 $(42.8 \%)$ maternal and fetal causes, and $15(53.6 \%)$ fetal causes. It is important to notice the occurrence of nine deaths whose basic cause was congenital anomaly (32.1\%)

In view of the results obtained, it is important to emphasize the relationship of the proportion of neonatal deaths in the first hours of life and the proportion of fetal deaths to the quality of the care offered in the women's pregnancy-puerperal cycle. Therefore, to reduce infant and perinatal mortality, it is necessary to undertake greater efforts so that the healthcare actions reflect improvements in access and quality of care.

- Brasília : Editora do Ministério da Saúde, 2012.

10. Almeida MF, Alencar GP, Schoeps D, Minucci EG et al. Qualidade das informações de óbito fetal em São Paulo, SP. Rev. Saúde Pública. 2011, vol.45, n.5, 845-853. Doi:10.1590/S003489102011005000058.

11. Schramm JMA e Szwarcwald CL. Sistema hospitalar como fonte de informações para estimar a mortalidade neonatal e a natimortalidade. Rev Saúde Pública 2011,45(5):845-53

12. Miura E, Failace LH e Fiori H. Mortalidade perinatal e neonatal no Hospital de Clínicas de Porto Alegre. Revista da Associação Médica Brasileira, 1997, 43(1). Doi: 10.1590/S010442301997000100009

13. Leal MC, Gama SGN, Campos MR, Cavalini LT, Garbayo LS, Brasil CLP et al. Fatores associados à morbimortalidade perinatal em uma amostra de maternidades públicas e privadas no Município do Rio de Janeiro, 1999-2001. Cad. Saúde Pública, 2004, 20 Sup 1:S20-S33.

14. Andrade CLT, Szwascwald CL, Gama SGN e Leal MC. Desigualdades sócio-econômicas do baixo peso ao nascer e da mortalidade perinatal no Município do Rio de Janeiro, 2001. Cad. Saúde Pública,2004, 20 Supl. I, 2004.

15. CEINFO. Boletim CEINFO em Dados. Dados e indicadores para a saúde: 12, SMS, São Paulo, 2012.

16. Fonseca SC e Coutinho ESF. Características biológicas e evitabilidade de óbitos perinatais em uma localidade na cidade do Rio de Janeiro, 1999 a 2003. Rev. Bras. Saúde Materno Infantil 8(2) Recife, jan-março, 2008.

17. Almeida MF, Alencar GP, Novaes HMD e Ortiz LP. Sistemas de Informação e mortalidade perinatal: conceitos e condições de uso em estudos epidemiológicos. Rev. Brasileira de Epidemiologia, 9(1) são Paulo, março 2006. 
18. WHO. Appropriate technology for birth. Lancet. 1985, Aug 24,2(8452):436-7. Doi: 10.1016/S0140-6736(85)92750-3

19. Martin JA, Hamilton BE, Ventura SJ, et al. Births: Final data for 2009. National vital statistics reports, vol $60 n^{\circ} 1$. Hyattsville, MD: National Center for Health Statistics. 2011. Número de páginas e se possível, aquelas utilizadas!

20. Ministério da Saúde, Brasil. As cesarianas no Brasil: situação no ano de 2010, tendências e perspectivas. In: Secretaria de Vigilância em Saúde/MS. Saúde Brasil 2011: uma análise da situação de saúde e de evidências selecionadas de impacto de ações de vigilância em saúde. Disponível em: http://portalsaude.saude. gov.br/portalsaude/arquivos/pdf/2013/Fev/21/ saudebrasil 2011_parte2_cap16.pdf. Acessado em: 31/10/2013. Pág. 373-97.

21. Ventura, GAB. Viabilidade da redução de cesáreas em maternidade universitária pública no município de São Paulo. [Tese de Doutorado]. São Paulo: Faculdade de Saúde Pública / Universidade de São Paulo, 1998.

22. Laurenti R, Silveira $M H$ e Siqueira AAF. Mortalidade Perinatal em São Paulo, Brasil. Revista de Saúde Pública, 1975, 9:115-24.
23. Chiavegatto Filho, ADP e Laurenti, R. O sexo masculino vulnerável: razão de masculinidade entre óbitos fetais brasileiros. Cadernos de Saúde Pública, 2012, 28:720-8. Doi: 10.1590/ S0102-311X2012000400011

24. Aquino MMA. Causas e Fatores Associados ao Óbito Fetal. Dissertação de Mestrado. Campinas: Faculdade de Ciências Médicas, Universidade Estadual de Campinas, 1997

25. Barros, FC, Victora, CJ, Vaughan, JP,. Causas de mortalidade perinatal em Pelotas, RS, Brasil. Utilização de uma classificação simplificada. Rev. de Saúde Pública, 1989, 21:310-6. Doi: 10.1590/S0034-89101987000400004

26. Araújo, BF, Bozzetti, MC e Tanaka, ACA. Mortalidade neonatal precoce no Município de Caxias do Sul: um estudo de coorte. Jornal de Pediatria, 2000, 76: 200-6. Doi: 0021-7557/ 00/76-03/200

27. CFM - Conselho Federal de Medicina. Resolução 1601 de 9 de agosto de 2000 e Resolução 1779 de 11 de novembro de 2005. Disponível em: [http://portal.cfm.org.br/] Acesso em: 30 out 2013. 